\title{
YELLOW-BREASTED CHAT NEAR RIDING MOUNTAIN NATIONAL PARK, MANITOBA
}

\section{WILLIAM J. WALLEY, Dauphin Regional Comprehensive Secondary School, 330 Mountain Road, Dauphin, Manitoba. R7N 2V6}

The Yellow-breasted Chat is accidental in Manitoba. ${ }^{4}$ its closest known breeding range is in southern Saskatchewan and Alberta, western North Dakota, South Dakota and southern Minnesota. ${ }^{7}$ In Canada, it nests in shrubby thickets and tangles along streams and ponds and in overgrown bushy clearings. ${ }^{2}$ Early Manitoba records (to 1969) were reported by Lane and Miller. ${ }^{3}$

"Oak Alley Hill" (OAH) is the author's name for a semi-open Bur Oak (Quercus macrocarpa)-hazelnut (Corylus sp.) habitat surrounded by aspen woods on the gravel beaches of former Lake Agassiz. The site is at the base of the Manitoba escarpment $18 \mathrm{~km}$ sse of Dauphin, just outside the north boundary of Riding Mountain National Park.

At $0730 \mathrm{~h}, 6$ June 1987, vibrating "burrm" notes, assumed to be those of a resident Scarlet Tanager, carried through the calm and warming morning air from the se corner of OAH. The call was followed to a hillside bushy clearing dominated by Chokecherry (Prunus virginiana) and Saskatoon (Amelanchier alnifolia) shrubs with a few American Elms (Ulmus americana) and Manitoba Maples (Acer negundo). Loud "Whuck, whuck, whuck" calls suggested that a Pileated Woodpecker was also nearby.

Concealed in dense foliage, the bird delivered various weird calls and notes indicating that a mimic bird as well as a Pileated Woodpecker were present. Other calls included: "Red-eyed Vireo" scolding noted and other impatient scolding noted, Robin-like notes and owl-like hoots. The calls were neither those typical of the Gray Catbird or the Brown Thrasher, which left the only possible mimic bird being the Northern Mockingbird, a rare species in the Dauphin-Riding Mountain National Park area. Suddenly, a rich patch of yellow was spotted and shortly, the bird emerged into full view in brilliant sunshine-a Yellow-breasted Chat. (The bird was viewed at $15 \mathrm{~m}$ with the use of $7 \times 35$ binoculars.)

The chat had been concealed in the foliage of an isolated elm with dense leaves growing close to the trunk and large limbs with Bittersweet (Celastrus scandens) vines spiralling upwards through the tree in this tangle of shrubs. This elm was favoured by the bird during the one and a half hours of observations.

There was no mistaking the species. Its size and plumage were identical to those shown and described in several field guides. ${ }^{56,7}$ The lemon breast was stunning among the green leaves of the elm and blue of the sky. The bird was a male as indicated by its black mouth lining and lores. In females, the mouth lining is red or pink; the lores gray. ${ }^{1}$ The territorial display has been described as one of the weirdest in the 
bird world. The chat ascended into the air wings flapping slowly and being lifted high, the tail pumping up and down, with the legs dangling downwards. The bird hovered or flew slowly for short distances well below tree top level. The bizarre vocalizations continued during this performance which was repeated several times. The calls have been described as wolf whistles, whistles, squawks, scolding mows, grunts, nasal quacks, foghom, cat calls, chortles, rattles, caws, chattering clucks, cackles, trumpet sounds and a chuckling high-pitched laugh. ${ }^{1,5,6,7}$ The bird also calls at night. ${ }^{1}$ Pough states that in its range, it is more often heard than seen. ${ }^{6}$ The ventribquistic quality of the chat's call has been noted by Hal Harrison. ${ }^{1}$ Peterson describes its call as being like those of a mimic bird, especially the Northern Mockingbird. In recent years the species has wandered north after the breeding season, which obviously was not the case with this bird.

The chat remained in or on the periphery of the thicket area the duration of the observation. However, it be- came progressively more shy. I was unable to retum to the area until the early moming of 8 June when F. Fisher and I were unable to bcate the bird, nor was it identified in subsequent trips through the summer.

1. HARRISON, H.H. 1984. Wood warbler's world. Simon and Schustor, New York. 335 pp.

2. GODFREY, W.E. 1986. The birds of Canada. Nat. Mus. of Canada, Ottawa. $595 \mathrm{pp}$.

3. LANE, JOHN and WAYNE MILLER. 1969. Sight records for the Yellow-breasted Chat in southwestem Manitoba. B/vo Jay 27:215.

4. MANITOBA AVIAN RESEARCH COMMITTEE. 1986. Field Checklist of the birds of Manitoba.

5. PETERSON, R.T. 1980. A field guide to the birds of eastem and central North America. Houghton Mifflin, Boston. 384 pp.

6. POUGH, N.R.H. 1949. Audubon land bird guide. Doubleday, Garden City, NY. $312 \mathrm{pp}$.

7. SCOTT, S.L. 1983. Field guide to the birds of North America. Nat Geog. Soc., Washington, D.C. 464 pp.

M.K. Rowan appealed in Bokmakierie (South Africa) for "a word to describe all the people interested in birds, but without the overtones and invidious distinctions" accompanying most designations. One reply was "a term with all the charm and flavour of the French tongue, a word with a little bit of nonsense in it, and one which symbolizes all the fun of birding." Thus from now onwards all our company will be known to me as "WASUISTS" or, if you prefer the original orthography, as "OISEAUISTS." Blue Jay 15:\#1. 1963. 